BJHS 48(3): 455-473, September 2015. C British Society for the History of Science 2015. This is an Open Access article, distributed under the terms of the Creative Commons Attribution licence (http://creativecommons.org/licenses/by/3.0/), which permits unrestricted re-use, distribution, and reproduction in any medium, provided the original work is properly cited.

doi:10.1017/S0007087415000278 First published online 14 May 2015

\title{
Phrenology, heredity and progress in George Combe's Constitution of Man
}

\author{
BILL JENKINS*
}

\begin{abstract}
The Constitution of Man by George Combe (1828) was probably the most influential phrenological work of the nineteenth century. It not only offered an exposition of the phrenological theory of the mind, but also presented Combe's vision of universal human progress through the inheritance of acquired mental attributes. In the decades before the publication of Darwin's Origin of Species, the Constitution was probably the single most important vehicle for the dissemination of naturalistic progressivism in the English-speaking world. Although there is a significant literature on the social and cultural context of phrenology, the role of heredity in Combe's thought has been less thoroughly explored, although both John van Wyhe and Victor L. Hilts have linked Combe's views on heredity with the transformist theories of Jean-Baptiste Lamarck. In this paper I examine the origin, nature and significance of his ideas and argue that Combe's hereditarianism was not directly related to Lamarckian transformism but formed part of a wider discourse on heredity in the early nineteenth century.
\end{abstract}

\section{Introduction}

George Combe (1788-1858) was Britain's leading phrenologist in the first half of the nineteenth century. His writings have been described by Steven Shapin as 'the most important vehicle for the diffusion of naturalistic and materialistic views in early to mid-nineteenthcentury Britain'. ${ }^{1}$ These ideas were largely presented to the reading public through the medium of Combe's most important work, the Constitution of Man, first published in 1828. Over the course of the century it comfortably outsold comparable books, such as Robert Chambers's Vestiges of the Natural History of Creation (1844) and Charles Darwin's Origin of Species (1859). It was a publishing phenomenon, having sold 100,000 copies in Britain and around 200,000 copies in America by $1860 .^{2}$ It has been

* Science Studies Unit, Science, Technology and Innovation Studies, University of Edinburgh, Old Surgeons' Hall, High School Yards, Edinburgh, EH1 1LZ. Email: writetobillj@yahoo.co.uk.

I would like to thank John Henry and Catherine Laing for their many helpful comments and suggestions, and Charlotte Sleigh, Jon Agar and the anonymous reviewers of BJHS for their valuable and constructive suggestions for improvements to this paper. I should also like to thank Elizabeth Singh of the Royal Medical Society of Edinburgh for allowing me access to the society's archives. This work was supported by the Economic and Social Research Council (ES/J500136/1).

1 Steven Shapin, 'Edinburgh and the diffusion of science in the 1830s', in Ian Inkster and Jack Morrell (eds.) Metropolis and Province: Science in British Culture, 1780-1850, London: Hutchinson, 1983, pp. 151-178, 158.

2 John van Wyhe, Phrenology and the Origins of Victorian Scientific Naturalism, Aldershot: Ashgate, 2004, p. 128. 
estimated that this made it the fourth-best-selling book in Britain in the second quarter of the century after the Bible, Pilgrim's Progress and Robinson Crusoe. ${ }^{3}$ It was also enormously influential; the Constitution has been described by John van Wyhe as 'one of the most important books of the second quarter of the nineteenth century'. ${ }^{4}$ As James Secord has pointed out, the book grew and expanded over many editions, and so 'was effectively not a single work, but a serial production'. ${ }^{5}$ As for the ideas contained in this book, in his Life of Richard Cobden John Morley considered that its 'principles have now in some shape or form become the accepted commonplaces of all rational persons'. 6 Sales of the first three editions were in fact relatively modest, and only really took off after the appearance of a cheap 'People's Edition', published in Edinburgh by William and Robert Chambers in 1835. This edition was subsidized by a bequest from William Henderson, a wealthy supporter of phrenology, which allowed the book to be priced at only $1 \mathrm{~s} 6 \mathrm{~d}$. Unlike earlier works by Combe, the Constitution was not merely a phrenological manual. Much more than this, it presented an all-encompassing vision of human nature and humanity's relationship with the natural world, with the idea of universal progress at its heart.

A discussion of the hereditary transmission of mental and physical traits forms an important component of Combe's argument in the Constitution. However, relatively few scholars have commented on the importance of these hereditarian doctrines in Combe's work. Three who have addressed this aspect of his thought to some extent are Victor L. Hilts, John C. Waller and John van Wyhe. In general, these scholars have viewed Combe's use of hereditarian ideas in the light either of Lamarckian transformism or of later Darwinian and post-Darwinian evolutionary thought. In a paper on phrenological views of heredity published in 1982, Hilts suggested that the hereditarian ideas of Combe made him a precursor of the social Darwinists and eugenicists of the late nineteenth and early twentieth centuries. However, he also noted that Combe's ideas differed from theirs in several crucial respects. These differences included Combe's emphasis on the duty of the individual to obey the laws of heredity and his emphasis on the dangers of in-breeding. ${ }^{7}$ In 2001 Waller published a paper that similarly set out to demonstrate the early nineteenth-century genealogy of social Darwinist and eugenicist ideas, and to demonstrate that Francis Galton's role as the 'father' of the eugenics movement had been overstated. ${ }^{8}$ To this end he focused on the hereditarian ideas of George Combe and his brother Andrew as evidence for the prevalence of the doctrine of hereditary transmission before 1859. Van Wyhe, in a detailed study of Phrenology and the Origins of Victorian Scientific Naturalism (2004), gave some attention to the

3 Roger Cooter, The Cultural Meaning of Popular Science: Phrenology and the Organization of Consent in Nineteenth-Century Britain, Cambridge: Cambridge University Press, 1984, p. 120.

4 Van Wyhe, op. cit. (2), p. 109.

5 James A. Secord, Visions of Science: Books and Readers at the Dawn of the Victorian Age, Oxford: Oxford University Press, 2014, p. 194.

6 John Morley, The Life of Richard Cobden, vol. 2, London: Chapman and Hall, 1881, p. 93.

7 Victor L. Hilts, 'Obeying the laws of hereditary descent: phrenological views on inheritance and eugenics', Journal of the History of the Behavioral Sciences (1982) 18, pp. 62-76.

8 John C. Waller, 'Ideas of heredity, reproduction and eugenics in Britain, 1800-1875', Studies in the History and Philosophy of the Biological and Biomedical Sciences (2001) 32(3), pp. 457-489. 
hereditarian strand in phrenological thought, and in that of Combe in particular, and its wider impact on later nineteenth-century ideas. Van Wyhe noted that Combe's 'talk of inheritance, which extended from Man to domesticated animals and their variability, brought to a vast reading audience many of the themes for which Darwin is now better known'. 9 Both Van Wyhe and Hilts have drawn parallels between Combe's hereditarianism and Lamarckian transformism. The discourse on heredity has therefore often been seen as merely one facet of a wider discourse on the mutability of species. The idea that traits acquired during the lifetime of a living thing can be transmitted to offspring, an idea now largely associated with the transformism of Jean-Baptiste Lamarck (1744-1829) and his followers, is particularly open to such interpretations. In this paper I will attempt to question the bracketing of Combe's hereditarian ideas, including that of the inheritance of acquired characteristics, with the transmutationist theories with which they are often associated. In order to do this I will look not only at the role of hereditarian ideas in the argument of Combe's book, but also at the sources from which he drew these ideas. My conclusion is that these beliefs, so much associated with evolutionary discourses in the minds of modern readers, may have simply represented a common-sense view of inheritance in the context of the period.

\section{Combe the phrenologist}

Combe was the most influential phrenologist in Britain during the middle decades of the nineteenth century. He had been a successful Edinburgh lawyer until he retired to devote himself entirely to phrenology in 1833 . An early convert to this would-be science, his first contact with the subject was through an extremely negative critique of phrenology written by John Gordon, which he had read in the June 1815 number of the Edinburgh Review. At the time, this convinced him that the doctrines described were 'contemptibly absurd'. ${ }^{10}$ However, not long after this, in 1816, Combe attended the dissection of a brain by Johann Casper Spurzheim (1776-1832), the great German popularizer of the presumptive science, at the house of a friend. After attending a course of lectures by Spurzheim, he 'arrived at complete conviction of the truth of Phrenology'. ${ }^{11}$ His growing interest in the subject led him to found the Edinburgh Phrenological Society in 1820 . He published a number of works on phrenology, including Essays on Phrenology (1819) and A System of Phrenology (1824), but it was the Constitution of Man, published in 1828, that was to be his most influential and bestselling work.

The fundamental principle behind phrenology was the presupposition that the brain is composed of a number of separate organs, each of which corresponds to a faculty of the human mind. According to phrenologists - although this was vociferously disputed at the time by their critics - the shape of the skull faithfully mirrors the form of the brain within in such a way that the development of these different organs can be read by a

9 Van Wyhe, op. cit. (2), p. 122.

10 George Combe, A System of Phrenology, 3rd edn, Edinburgh: John Anderson, 1830, p. iii.

11 Combe, op. cit. (10), p. iv. 
skilled practitioner from the shape of the skull. For Combe there were thirty-five such organs, two more than the thirty-three proposed by Spurzheim, and significantly more than the twenty-seven suggested by Franz Josef Gall (1758-1828), the founder of phrenology. In the Elements of Phrenology Combe summarized the essentials of his doctrine as follows: 'the brain is the material instrument by means of which the mind acts, and is acted upon; and it is a congeries of organs'. ${ }^{12}$ These organs could be divided into those common to humans and the animals, such as 'amativeness', 'destructiveness' and 'secretiveness', and those proper to humanity alone, such as 'veneration', 'hope' and 'ideality'. These views were at extreme variance with the dominant image of the mind in the early nineteenth century, and especially with those of the influential Scottish Common Sense school of philosophy, as explored in a recent paper by Sean Dyde. ${ }^{13}$ Followers of the Common Sense school saw the mind as a mysterious, indivisible monad, the 'thinking principle' of Thomas Reid (1710-1797), whose attributes could only be studied through introspection. ${ }^{14}$ However, as we will see below, Combe's Constitution was much more than just an exposition of the doctrine of the phrenological organs. This topic, in fact, only accounts for a relatively small proportion of the work. Combe's vision of human nature was not a static one, but a story of progress and development.

\section{Phrenology and heredity}

On the evidence of the debate on the transmission of hereditary characteristics in eighteenth-century France, Carlos López-Beltrán has pointed out that 'gathering of convincing cases of hereditary transmission of a wide range of different characteristics, and the progressive closing of alternative avenues of dealing with them (such as their ascription to chance, or their sheer irrelevance), was one of the central themes of the eighteenthcentury debates around generation'. ${ }^{15}$ By the early decades of the nineteenth century the inheritance of both positive and negative traits of mind and body was therefore well established as a subject of lively debate. The 1820 s were a particularly crucial period for the development of this concept. As Waller has noted, the field of heredity was dominated at this time by three groups: stock breeders and horticulturalists, ethnologists and medical practitioners. ${ }^{16}$ The medical men were principally preoccupied with the way hereditary diseases could be transmitted in families. Their main concern was how to avoid the transmission of undesirable traits from generation to generation. The stock breeders and horticulturalists were interested both in how the transmission of desirable qualities could be assured, and in how the inheritance of undesirable ones could be avoided.

12 George Combe, Elements of Phrenology, 3rd edn, Edinburgh: John Anderson, 1828, p. 23.

13 Sean Dyde, 'Combe and common sense', BJHS, published online 11 December 2014, available on CJO 2014, doi:10.1017/S0007087414000922.

14 See, for example, Thomas Reid, An Inquiry into the Human Mind on the Principles of Common Sense Edinburgh: Edinburgh University Press, 1997, p. 13.

15 Carlos López-Beltrán, 'Forging heredity: from metaphor to cause, a reification story', Studies in the History and Philosophy of Science (1994) 25(2), pp. 211-235, 219.

16 Waller, op. cit. (8), p. 459. 
Ethnologists had more of a theoretical interest in the question. For them, the prime interest of heredity lay in its relevance to the question of race. There was much discussion in this period of whether racial characteristics were fixed for all time or whether they were the result of the different climates in which the different races found themselves. The latter possibility raised the thorny question of why races did not rapidly transform under the influence of their new environment when transplanted to different climates. The attempts of ethnologists to resolve this problem sparked a lively debate on the origins of varieties in the human species, and the genealogy of the races. Combe was to draw on the work of all three groups in his writings on heredity.

The first edition of the Constitution contained a section on 'transmission of hereditary qualities'. The fourth, People's Edition, of 1835 additionally included substantial appendices on the 'hereditary descent of national peculiarities' and 'hereditary transmission of qualities'. Combe accounted for these phenomena by reference to the brain, claiming that the 'brain is a portion of our organised system, and, as such, is subject to organic laws, by one of which, as already observed, its form, size, and qualities, are transmitted by hereditary descent'. ${ }^{17}$ In his speculations on the subject of heredity, Combe cited as an influence the writings of the noted eighteenth-century Scottish physician and professor of medicine at the University of Edinburgh John Gregory (1724-1773), who wrote a Comparative View of the State and Faculties of Man with Those of the Animal World, first published in 1765. In this work, Gregory had explored the analogies between humanity and the animal creation. One of the analogies identified by Gregory related to the hereditary transmission of characteristics and the way in which this could be used to improve both domesticated animal species and the human race through selective breeding. He wrote that 'by a proper attention we can preserve and improve the breeds of Horses, Dogs, Cattle, and indeed of all other animals. Yet it is amazing that this Observation was never transferred to the Human Species, where it is equally applicable'. ${ }^{18}$ Combe used Gregory's work to demonstrate that it had long been recognized that both mental and physical traits were transmitted from generation to generation among humans, just as they were among animals.

In making his case, Combe also made extensive use of the second edition of James Cowles Prichard's Researches into the Physical History of Mankind (1826). Prichard (1786-1848) was a medical graduate of the University of Edinburgh who went on to become a physician and ethnologist. He wrote widely on all aspects of human nature and the mind. His ethnological writings were very influential in the mid-nineteenth century, although the religious slant of his works caused them to go rapidly out of favour after his death. ${ }^{19}$ Partly from religious conviction, Prichard was a strong monogenist, and his Researches was originally written as a refutation of Lord Kames's polygenist theories. To this end he explored not only heredity, but also the nature and causes

17 George Combe, The Constitution of Man Considered in Relation to External Objects, 4th edn, Edinburgh: William and Robert Chambers, 1835, p. 43.

18 John Gregory, Comparative View of the State and Faculties of Man with those of the Animal World, 7th edn, London: John Dodsley, 1777, p. 21.

19 H.F. Augstein, 'Prichard, James Cowles (1786-1848)', Oxford Dictionary of National Biography, Oxford: Oxford University Press, 2004, at www.oxforddnb.com/view/article/22776, accessed 12 August 2013. 
of variations in humans and animals. In the following passage from the second edition he gave a summary of his views of the hereditary transmission of varieties:

It appears to be a general fact, that all connate varieties of structure [variations present since birth], or peculiarities which are congenital, or which form a part of the natural constitution impressed on an individual from his birth, or rather from the commencement of his organization, whether they happen to descend to him from a long inheritance, or to spring up for the first time in his own person - for this is perhaps altogether indifferent - are apt to reappear in his offspring. ${ }^{20}$

Although he does not explicitly cite the works of Spurzheim in his discussion of heredity in the Constitution, it seems clear that Combe was also influenced by his A View of the Elementary Principles of Education, first published in 1821, which was the first phrenological work to deal at length with heredity. ${ }^{21}$ In this work Spurzheim stated that "children participate in the bodily configuration and constitution of their parents, and also in their tendencies to particular manifestations of the mind'. ${ }^{22}$ Spurzheim considered that these ideas ought to be put into practice to improve the race, prefiguring many of the arguments of the eugenicists. He claimed that it 'is indeed a pity that the laws of hereditary descent are so much neglected, whilst, by attention to them, not only the condition of single families, but of whole nations, might be improved beyond imagination, in figure, stature, complexion, health, talents and moral feelings' ${ }^{23}$ Many of the measures he suggests, such as discouraging people from having children when they are too young or too old, have direct echoes in the Constitution, and it is clear that Spurzheim was a major source for Combe's ideas. On the question of the perfectibility of human nature, Spurzheim admitted that some degree of improvement was possible, but that 'it is not to be understood that man may lose one faculty and acquire another; for the fundamental nature of man being unchangeable, in body as well as in the faculties of the mind, such an event is impossible on earth'. He allowed only that 'certain powers are capable of attaining greater or lesser activity'. ${ }^{24}$ The key to the progress of the race for Spurzheim lay in selective breeding, rather than the improvement of the individual through social engineering. As we will see below, this is an important point of difference from Combe, who made a strong connection between the development of the individual in society and universal progress.

Influenced by Spurzheim, and drawing on the works of writers such as Gregory and Prichard, Combe applied hereditarianism to the mental organs revealed by phrenology. According to the Constitution,

Phrenology reveals the principle on which dispositions and talents are thus hereditary. Mental qualities are determined by the size, form, and constitution of the brain. The brain is a portion

20 James Cowles Prichard, Researches into the Physical History of Mankind, vol. 2, London: John and Arthur Arch, 1826, p. 536.

21 Hilts, op. cit. (7), p. 63.

22 G. Spurzheim, A View of the Elementary Principles of Education, Founded on the Study of the Nature of Man, 2nd edn, Boston, MA: Marsh, Capen and Lyon, 1833, p. 37.

23 Spurzheim, op. cit. (22), p. 46.

24 Spurzheim, op. cit. (22), p. 2. 
of our organised system, and, as such, is subject to the organic laws, by one of which, as already observed, its form, size, and qualities, are transmitted by hereditary descent. ${ }^{25}$

For Combe the form, size and qualities of the phrenological organs were determined by heredity. But, as we shall see in the next section, for Combe the character of the individual was determined not simply by the relative size of the organ, but by the relationship between its size and its activity.

\section{Developing the faculties}

For Combe, even if the relative size of a phrenological organ was fixed for the lifetime of the individual, its activity could vary according to circumstances and the level of stimulation provided by the social and physical environment. The activity of the organs could clearly be subject to change during the lifetime of the person, and this would be reflected in changes in the person's character. The ways in which the faculties of the mind manifested themselves in the character of the individual were therefore dependent to a significant extent on their relations with the external world. Combe considered that the world had been constituted in such a way that humanity was subject to a series of unbending natural laws. He further believed that the constitution of the human mind corresponded directly to the constitution of the world, and hence to the natural laws which governed it. There was therefore an ideal harmony between the world and the mind, which it was humanity's duty to discover and maintain. According to Combe, there was a direct relationship between the development of the brain during the lifetime of the person and the extent to which they obeyed the natural laws. He emphasized the centrality of the concept of natural law to his thought in a letter to Robert Chambers in December 1833:

The leading principles of the 'Constitution of Man', to which I attach value, \& which seem to myself to be original, are, the separate existence \& operation of each natural law; the necessity of obeying all of them; $\&$ the evident adaptation of all to the moral $\&$ intellectual advancement of the race. ${ }^{26}$

The natural laws could be divided into three categories: the physical, the organic and the moral or intellectual laws. According to Combe, the physical laws are those which determine that an unsound ship will sink, while a sound one will float; the organic laws determine that an individual who has a healthy diet and takes exercise will be physically sound, while one who has a bad diet and does insufficient exercise will become ill; and the moral laws ensure that a person who 'obeys the precepts of Christianity, will enjoy within himself a fountain of moral and intellectual happiness' ${ }^{27}$ According to the arrangement of the Constitution, heredity comes under the heading of 'organic law', although it would seem evident that it would also have applied to the moral laws when it related to the hereditary transmission of the higher, moral faculties of the mind. Obedience to the natural laws would lead to a healthy development of the

25 Combe, op. cit. (17), p. 43.

26 George Combe to Robert Chambers, 15 December 1835, Robert Chambers, letters of noted persons, 1833-1838, National Library of Scotland, Dep. 341/91, 13, underlining in original.

27 Combe, op. cit. (17), p. 6, original emphasis. 
higher faculties through promoting the activity of the corresponding phrenological organs, while disobedience or ignorance of them could conversely be deeply harmful and lead to degeneration. The latter situation was generally brought about by giving the lower, 'animal' faculties free reign. According to Combe, living in harmony with the natural laws had a profound positive influence on the brain. As he put it, 'A perception of the importance of the natural laws will lead to their observance, and this will be attended with an improved development of brain'. ${ }^{28}$ The development of the faculties of the mind, as for any other organs of the body, was stimulated by their use, which was in turn guaranteed by following the dictates of the natural laws. Combe summed up his theory of the human mind in the following passage:

The best mode of increasing the strength and energy of any organ and function, is to exercise them regularly and judiciously, according to the laws of their constitution. The brain is the organ of the mind; different parts of it manifest different faculties; and the power of manifestation in regard to each is proportionate, caeteris paribus, to the size and activity of the organ. The brain partakes of the general qualities of the organised system, and is strengthened by the same means as the other organs. ${ }^{29}$

\section{George Combe: social Lamarckian?}

We have seen above that Combe believed that the faculties of the mind could be developed during the lifetime of the individual. But Combe also believed that these acquired traits could be inherited by offspring. After considering and rejecting the possibilities that the qualities of the brain are identical to the parent of the same sex, or an amalgam of the qualities of the two parents, Combe settles on the formula that the 'qualities of the child are determined jointly by the constitution of the stock, and by the faculties which predominate in power and activity in the parents at the particular time when the organic existence of each child commences'. ${ }^{30}$ In his advocacy of the inheritance of acquired characteristics, some writers have seen echoes of the transformist theories of Lamarck. When Combe pronounced that 'the children of the individuals who have obeyed the organic, the moral, and the intellectual laws, will not only start from the highest level of their parents in acquired knowledge, but will inherit an enlarged development of the moral and intellectual organs', it is easy to see how such a doctrine could be described as social Lamarckism. ${ }^{31}$ Victor L. Hilts has even suggested that Combe had 'resurrected Lamarck'. ${ }^{32}$ John van Wyhe has also noted that Combe's 'law of hereditary descent would today be called "Lamarckian inheritance". 33 But is there a genuine connection between Combe's views and Lamarckism, or are Combe's theories more likely to have

28 Combe, op. cit. (17), pp. 97-98.

29 Combe, op. cit. (17), p. 34.

30 Combe, op. cit. (17), p. 44.

31 Combe, op. cit. (17), p. 49.

32 Hilts, op. cit. (7), p. 74.

33 John van Wyhe, 'George Combe's law of hereditary descent', in A Cultural History of Heredity II: 18th and 19th Centuries, Max Planck Institute for the History of Science, Preprint 247 (2003), at www.mpiwgberlin.mpg.de/Preprints/P247.PDF, consulted 24 September 2013, p. 168. 
been grounded on ideas of heredity that were commonplace in the early decades of the nineteenth century?

In the first volume of his influential book on the Histoire naturelle des animaux sans vertèbres (1815), Lamarck set down the four fundamental laws that underpinned his theory of transformism:

First law: Life, by its own forces, tends continually to increase the volume of every body that possesses it, and extends the dimensions of those parts up to a point determined by itself.

Second law: The production of a new organ in the animal body results from a new need which continues to make itself felt, and a new movement which this need brings about and supports.

Third law: The development of organs and their force of action are constantly in proportion to the use of these organs.

Fourth law: All that which has been acquired or changed in the organization of individuals during the course of their lives, is conserved by generation, and transmitted to the new individuals descended from those who underwent the changes. ${ }^{34}$

It is certainly not difficult to draw parallels between Combe's ideas on the development and inheritance of mental faculties and Lamarck's third and fourth laws. However, the fixity of the phrenological organs seems quite counter to the second law, which deals with the development of new organs. In Combe's writings there is no suggestion that the organs that composed the human brain could be gained or lost through use or disuse; there would therefore always be a strict limit on the development that was achievable. On the contrary, all evidence shows 'that every creature and every physical object has received a definite constitution, and been placed in certain relations to other objects' ${ }^{35}$ This applied as much to the organs of the mind as to those of the body. That humanity could perfect itself through its own moral and intellectual exertions was one thing, but for it to be transformed into an entirely new species was quite another, for which there is no evidence in the writings of Combe. In this, Combe seems to have followed the lead of Joseph Gall and Johann Spurzheim, the founders of phrenology, who criticized the transformist theories of Lamarck in a book on the Innate Dispositions of the Soul and the Mind (1811). They asked,

Is it not more in conformance with the wisdom of the Creator, which can be recognized in a blade of grass as well as in the arrangement of worlds, that, in the first instant of creation, every being, both inanimate and living, received its own particular properties, and was thus differentiated from all other beings? ${ }^{36}$

34 'Première loi: La vie, par ses propres forces, tend continuellement à accroître le volume de tout corps que la possède, et à étendre les dimensions de ces parties, jusqu'à un terme qu'elle amène elle-même. Deuxième loi: La production d'un nouvel organe dans un corps animal, résulte d'un nouveau besoin survenu qui continue de se faire sentir, et d'un nouveau mouvement que ce besoin fait naître et entretient. Troisième loi: Le développment des organes et leur force d'action sont constamment en raison de l'emploi de ces organes. Quatrième loi: Tout ce qui a été acquis, tracé ou changé, dans l'organisation des individus, pendant le cours de leur vie, est conservé par la génération, et transmis aux nouveaux individus qui proviennent de ceux qui ont éprouvé ces changemens'. Jean-Baptiste Lamarck, Histoire naturelle des animaux sans vertèbres, 7 vols., Paris: Verdiere, 1815-1822, vol. 1, pp. 181-182.

35 Combe, op. cit. (17), p. 1.

36 'N'est-il pas plus conforme à la sagesse du Créateur qui se fait reconnoître dans le brin d'herbe comme dans l'arrangement des mondes, que, dès le premier instant de la création, chaque être, inanimé et vivant, ait reçu ses propriétés particulières, et ait différé par-là de tous les autres?' F.J. Gall and G. Spurzheim, Des 
I turn now to the important question of how widely Lamarck's transformist theories were known in Edinburgh in the 1820s, at the time Combe was formulating the ideas on heredity that were to appear in his Constitution. There is, in fact little evidence for any significant interest in Lamarckian transformism in Edinburgh before the publication of his Histoire naturelle des animaux sans vertèbres in 1815-1822. This is perhaps not surprising, as Pietro Corsi has noted that it was to a considerable extent on the Histoire naturelle that Lamarck's Europe-wide reputation was built in the 1820 s. $^{37}$ An early reference appears in the preface to Cuvier's Theory of the Earth (1815) by Robert Jameson, the professor of natural history at the University of Edinburgh. ${ }^{38}$ This, however, only consists of a single sentence, which makes no reference to Lamarck's views on heredity. John Fleming, the Church of Scotland minister and natural historian, wrote a review of the Histoire naturelle for the Edinburgh Review in $1820 .{ }^{39} \mathrm{He}$ also included a critique of Lamarck in Volume 1 of his Philosophy of Zoology (1822). ${ }^{40}$ However, Fleming too did not address the issue of the inheritance of acquired characteristics, concentrating rather on a defence of vitalism against Lamarck's materialist theory of life. While Fleming was generally dismissive of Lamarck's theories, his friend Robert Grant, lecturer at John Barclay's extramural anatomy school and invertebrate zoologist, was an enthusiastic admirer. ${ }^{41}$ Charles Darwin got to know Grant well in his time at the University of Edinburgh between 1825 and 1827, and we have his testimony for Grant's opinions on evolution. Darwin recounted in his autobiography how Grant 'burst forth in admiration of Lamarck and his views on evolution' one day while they were on a collecting trip together. ${ }^{42}$ Although Grant published a number of transformist articles in the Edinburgh New Philosophical Journal in the mid-1820s, none of these mentioned Lamarck by name, or referred specifically to the inheritance of acquired characteristics. An anonymous transformist article entitled 'Observations on the nature and importance of geology' and published in the same journal in 1826 did openly praise Lamarck, but again failed to mention his ideas on heredity. ${ }^{43}$ As I will explore below, Lamarck's views on heredity may simply have had such common currency in this period as not to have been considered worthy of comment.

Dispositions Innées de l'Ame et de l'Esprit, du Matérialisme, du Fatalisme et de la Liberté Morale, avec des Réflexions sur l'Education et sur la Législation Criminelle, Paris: F. Schoell, 1811, p. 100.

37 Pietro Corsi, The Age of Lamarck: Evolutionary Theories in France, 1790-1830, Berkeley: University of California Press, 1988, p. 63.

38 Georges Cuvier, Essay on the Theory of the Earth, 2nd edn (tr. Robert Kerr), Edinburgh: William Blackwood, 1815, p. vii.

39 [John Fleming], Review of Jean-Baptiste Lamark, Histoire naturelle des animaux sans vertèbres, Edinburgh Review (1820) 3(4), pp. 403-418.

40 John Fleming, The Philosophy of Zoology or a General View of the Structure, Functions, and Classification of Animals, vol. 1, Edinburgh: Archibald Constable, 1822.

41 See Adrian Desmond, 'Robert E. Grant: the social predicament of a pre-Darwinian transmutationist', Journal of the History of Biology (1984) 17(2), pp. 189-223.

42 Charles Darwin, The Autobiography of Charles Darwin, London: Collins, 1958, p. 49.

43 Anon., 'Observations on the nature and importance of geology', Edinburgh New Philosophical Journal (1826) 1, pp. 293-302. James Secord has suggested that the author of this article may well have been Robert Jameson; see James A. Secord, 'Edinburgh Lamarckians: Robert Jameson and Robert E. Grant', Journal of the History of Biology (1991) 24(1), pp. 1-18. 
The published sources noted above, along with a few other scattered references to Lamarck, for the most part negative in tone, are the scant evidence for the reception of Lamarckian transformism in Edinburgh in the 1820s. The one thing they have in common is that they were written by individuals with an interest in invertebrate zoology, for it was for his important contributions to invertebrate taxonomy that Lamarck was principally known at the time. It seems that his espousal of the inheritance of acquired characteristics was not considered important or contentious enough to merit a mention, let alone refutation, in published accounts of his theories. Outside the naturalhistory circles that included Jameson, Fleming and Grant, there is little or no evidence of any wider interest in Lamarck's theories in Edinburgh before the critique of Lamarck in the second volume of Lyell's Principles of Geology brought his theories to a wider audience in 1832. There is no evidence that any major Edinburgh phrenologist before Robert Chambers took any interest in transformism, and the Edinburgh Journal of Phrenology contains no articles touching on the subject between its foundation in 1823 and Combe's review of Vestiges in 1845.44

Combe himself seems to have been so little acquainted with developments in natural history that when he turned to the subject to bolster his views on universal progress in the 'introductory remarks' to the People's Edition of the Constitution (1835), he relied largely on lengthy quotations from Humphry Davy's Consolations in Travel, or, the Last Days of a Philosopher (1831). Combe was so unsure of himself on this territory that he wrote a letter to the botanist and phrenologist Hewitt Cottrell Watson in 1836 asking for his opinion on the geological history of the world presented in the introductory remarks', and in particular in the lengthy borrowings from Davy. In his reply Watson advised Combe to 'retain the passage, but intimate that it is merely a remote analogy, on which you lay no particular stress, \& whether correct or not so, of no essential importance to your own views touching on the progress of mankind'. ${ }^{45}$ Watson appended to his letter his own account of the 'Progress of the Earth's Changes', significantly more cautiously worded than the passage quoted from Davy. In it, Watson raised the possibility that the absence of fossils of higher forms of life from older rocks may simply be a product of the vagaries of the fossil record and the relative scarcity of higher forms in comparison with the lower. In the end Watson concluded that 'the evidence shows oscillation to \& fro, without any onward or backward course in continuity'. ${ }^{46}$ Despite Watson's misgivings, subsequent editions of the Constitution retained the passages from Davy. Evidently Combe had chosen to ignore Watson's advice on the matter. It would seem that the analogy between the progressive nature of the constitution of the globe and of the constitution of man was of too much importance to Combe for him to quietly drop the offending passage, or to amend it in line with Watson's recommendations. Combe seems to have been enraptured by the harmony between the perfectibility of human nature and the progressive story of the history of the globe presented by

44 [George Combe], Review of Vestiges of the Natural History of Creation, Phrenological Journal and Miscellany (1845) 18, 69-79.

45 Hewitt Cottrell Watson to George Combe, 14 September 1836, Correspondence of George Combe, National Library of Scotland, Ms 7241, f. 160r.

46 Watson, op. cit. (45), f. 161v. 
modern geology. As Combe wrote in the 'introductory remarks' to the People's Edition of the Constitution,

The constitution of the world ... appears to be arranged in all its departments on the principle of slow and progressive improvement. Physical nature itself has undergone many revolutions, and apparently has constantly advanced. Geology seems to show a distinct preparation of it for successive orders of living beings, rising higher and higher in the scale of intelligence and organisation, until man appeared..$^{47}$

It should be noted, however, that the progressive picture painted here of the fossil record is entirely in keeping with the writings of Georges Cuvier or William Buckland, both fierce opponents of transformism, and could be as easily explained by successive creations as by evolution. ${ }^{48}$

Although it seems highly unlikely that Combe was directly influenced by Lamarck's theories, it cannot be denied that his brother Andrew almost certainly had been exposed to transformist ideas while he was studying in Paris between October 1817 and July 1818. We know from the records of the Jardin du Roi that Andrew Combe had enrolled for Lamarck's course on invertebrate zoology in $1818 .{ }^{49}$ Many years later George Combe wrote an account of his brother's time in Paris in his biography of him. Here he related that while in Paris Andrew had attended lectures at the Jardin du Roi on botany by René Louiche Desfontaines, on chemistry by M. Langres, on geology by Barthélemy Faujas de Saint-Fond, and on physiology by Anthelme Richerand. ${ }^{50}$ However, there is no mention of Andrew Combe's attendance at Lamarck's lectures. If Combe had considered his brother's attendance at these lectures significant, he would surely have mentioned them in his biography, along with the others. Either he actively suppressed the attendance of his brother at Lamarck's lectures, not wishing to link his brother with controversial transformist ideas, or else he simply neglected to mention them. It is also possible that, although Andrew Combe enrolled for Lamarck's course, he did not actually attend any lectures. From the lack of evidence from other sources that Combe engaged either positively or negatively with Lamarck's theories, the latter two explanations seem the more plausible.

Some further indication of Combe's attitude towards the transmutation of species can be gleaned from his reaction to Vestiges of the Natural History of Creation. Having received a complimentary copy from his - and Chambers's - publisher, Combe wrote a letter to the anonymous author in October 1844, not realizing that the author was in fact his friend and fellow phrenologist. The letter is full of admiration for the work, and Combe thanked the author 'for much pleasure and instruction'. However, he

47 Combe, op. cit. (17), p. 2.

48 See, for example, Cuvier, op. cit. (38); and William Buckland, Geology and Mineralogy Considered with Reference to Natural Theology, 2 vols., London: William Pickering, 1836.

49 Pietro Corsi, 'Chronologie de la vie de Jean-Baptiste Lamarck, Le registre d'inscription au cours de Lamarck pour 1818', in Jean-Baptiste Lamarck: Works and Heritage, at www.lamarck.cnrs.fr/auditeurs/ index.php? rech=scan\&send=scan\&nom=tous\&cours=1818\&inscri=tous\&offset=48\&nbmax=4, consulted 5 January 2014.

50 George Combe, The Life and Correspondence of Andrew Combe, Edinburgh: Maclachlan and Stewart, 1850, pp. 56-60. 
concluded that the author's 'leading idea is not yet proved; it was impossible for you to do so in the present stage of science \& of man's experience; but you have invested it with probability, and brought so strong an array of phenomena to support it'. ${ }^{51}$ Significantly, there was no explicit reference to the transmutation of species, the most controversial aspect of his theory. By the 'leading idea' he appears to have been referring to the general concept of universal development laid out by Chambers, of which the transmutation of species was but one manifestation.

When the third edition of Vestiges was published, Combe again received a complimentary copy. Again he wrote to thank the anonymous author, this time at greater length. ${ }^{52}$ As in his previous letter, Combe made no comment on the doctrine of the transmutation of species, but rather devoted a substantial part of the letter to a detailed critique of the section of the book dealing with the development of human society, a subject clearly closer to Combe's heart. While we might have expected an avowal of Combe's views on transformism in a letter to the author of Vestiges, he has nothing to say on the subject. It can only be concluded that, while Combe was not in any way shocked or scandalized by the transformist doctrines expounded in Vestiges, as many of his contemporaries clearly were, neither were they of great interest to him. While he was prepared to countenance the possibility that Chambers's transformist doctrines might have been correct, he certainly did not consider that the case for them had been proved.

There is also strong evidence, from one of his staunchest critics, that Combe was no transformist, and that any analogy between his theory of human progress through the hereditary transmission of mental characteristics and Lamarckian transformism was almost certainly coincidental. In 1836, spurred on by the success of the People's Edition of the Constitution published the previous year, William Scott (1782-1841) published an attack on Combe's ideas entitled The Harmony of Phrenology with Scripture: Shewn in a Refutation of the Philosophical Errors Contained in Mr Combe's 'Constitution of Man'. Scott had himself been a leading phrenologist in Edinburgh and was a former president of the Edinburgh Phrenological Society. He knew Combe well, but had broken with him over Combe's doctrine of the natural laws and his advocacy of universal progress. Scott left the Edinburgh Phrenological Society in 1830 in the aftermath of a power struggle between Combe's faction and a group of evangelical phrenologists, of which Scott was one of the leading figures. Combe and his supporters had emerged from this struggle as the dominant faction within the society, now largely purged of its evangelical members. In his book, Scott dealt harshly with Combe, describing his theories as 'a low and grovelling system'. ${ }^{53} \mathrm{He}$ reserved particular scorn for Combe's progressivism, stating,

51 George Combe [to Robert Chambers], 30 October 1844, Combe papers, National Library of Scotland, Ms. $7388,780$.

52 George Combe [to Robert Chambers], 1 March 1845, Combe papers, National Library of Scotland, Ms. 7390, 66-71.

53 William Scott, The Harmony of Phrenology with Scripture: Shewn in a Refutation of the Philosophical Errors Contained in Mr Combe's 'Constitution of Man', Edinburgh: Fraser \& Co., 1836, p. 325. 
We have, therefore, every kind of evidence, positive and negative, for asserting, that neither in the vegetable nor in the animal creation is there any such thing as a natural state of progression; and that no race or species of either has ever, as a species, improved itself, or shewn any symptom of 'possessing within itself the elements of improvement'. ${ }^{54}$

However, one thing of which Scott never accused Combe was advocating transformism. Rather he noted that Combe 'distinctly and correctly states, that each new race of plants or animals was the result of a separate act of creation; and he states, moreover, in the very outset of his work, the general fact, that every creature, and every physical object, "has received its own definite constitution". 55 Scott knew Combe and his views well, and was under no obligation to spare him if he had evidence that he held opinions that could be used against him. It therefore seems more than likely that we can take Scott at his word when he declared Combe innocent of advocating the transformation of species.

\section{Combe and the inheritance of acquired characteristics}

Far from being an unusual or radical belief in the late eighteenth and early nineteenth centuries, it was widely acknowledged that acquired characteristics were heritable. Combe would not have had to go searching in Lamarck's treatise on invertebrate zoology to find the principle of the transmission of acquired traits; the idea was a relatively commonplace one. In a treatise published in 1775, the famous Scottish surgeon John Hunter (1728-1793) had written that 'there is no manner of doubt that peculiarities acquired by men do descend to their posterity'. ${ }^{56}$ Hunter applied these ideas both in a medical context, to conditions such as gout, scrofula and madness, and also to the effect of climate on racial characteristics. ${ }^{57}$ The German physiologist Johann Friedrich Blumenbach (1752-1840) agreed with Hunter; in the third edition of a treatise on race published in 1795 he commented that

the aboriginal Ethiopians have been for a long time and for many series of generations exposed to the actions of that climate ... So we must not be surprised if they propagate unadulterated, even under another climate to succeeding generations, the same disposition which has spread such deep and perennial roots in their ancestors from the most distant antiquity. ${ }^{58}$

In the second decade of the nineteenth century the theories of Blumenbach and Hunter were still debated by medical students at the University of Edinburgh in dissertations given to the Royal Medical Society. In the dissertation book for 1810-1811 can be found a paper entitled 'What are the Varieties of the Human Species; \& their causes?' by J. W. Stirk, in which it is stated that

54 Scott, op. cit. (53), pp. 16-17.

55 Scott, op. cit. (53), p. 12, original emphasis.

56 John Hunter, Disputatio inauguralis quedam de hominem varietatibus, et harem causis exponens (1775), in The Anthropological Treatises of Blumenbach and Hunter (tr. Thomas Bendyshe), London: Longman, Green, Longman, Roberts \& Green, 1865, p. 204.

57 Hunter, op. cit. (56), p. 386.

58 Johann Friedrich Blumenbach, De Generis Humani Varietate Nativa (1795), 3rd edn, in Anthropological Treatises of Blumenbach and Hunter, pp. 145-276, 204. 
changes, the effects of which blend with the general actions of the body, and ultimately form the character of a climate and nation, are progressively carried on through several generations, till the causes that produce them have attained their utmost operation, by becoming perfectly congenital to the system. ${ }^{59}$

The following year, in another dissertation on race, Nicholas C. Pitta expressed the same opinion - that changes effected by the climate could become heritable. ${ }^{60}$ Combe could certainly have come into contact with these ideas through the many medical men among his phrenological associates, including his brother Andrew.

However, Combe's evidence for the transmission of acquired traits seems to have come less from scholarly sources than from tales of natural curiosities, whether published or anecdotal, which were in circulation in the early nineteenth century (and are detailed below). This was the evidence that underpinned Combe's argument for social progress based on development of the phrenological organs; without a mechanism for the inheritance of the higher state achieved, the advances made by individuals would not be automatically passed on to succeeding generations. I would argue that his adoption of the inheritance of acquired characteristics was therefore a natural consequence of Combe's hereditarian views, his belief in the perfectibility of the faculties and his unerring faith in human progress. Although Prichard largely rejected the inheritance of acquired characteristics, his discussion of the subject may also have been a crucial source for Combe, influenced as he was by Blumenbach and Hunter. In the following paragraphs I will examine Combe's specific beliefs regarding the inheritance of acquired traits, starting with his rejection of Prichard's arguments against such transmission.

Prichard, in his Researches into the Physical History of Mankind, noted that 'changes produced by external causes in the appearance and constitution of the individual are temporary, and, in general, acquired characteristics are transient; they terminate with the individual, and have no influence on the progeny'. ${ }^{61}$ However, as H.F. Augstein has pointed out in her survey of Prichard's anthropology, his view on heredity evolved in the course of the four editions of his Researches. By the second edition in 1826, she notes, he had come to the rather awkward conclusion that, while the environment was responsible for racial differences in humans, such acquired attributes were not subject to hereditary transmission. ${ }^{62}$ The evident problems with this position must surely have been apparent to Combe when he set out to refute Prichard's views. Combe presented a number of counterarguments to Prichard and in favour of the inheritance of mental traits, with evidence drawn from a variety of sources, which he organized under four headings. These were: ' 1 st, The transmission of factitious or temporary conditions of the body; 2ndly, The transmission of acquired habits; $3 r d l y$, The appearance

59 J.W. Stirk, 'What are the Varieties of the Human Species; \& their causes?', Royal Medical Society, Dissertations 65 (1810-1811), pp. 317-318, Library of the Royal Medical Society.

60 Nicholas C. Pitta, 'What is the influence of climate on the human species? And what are the varieties of men which result from it?', Royal Medical Society, Dissertations 66 (1811-1812), pp. 284-285, Library of the Royal Medical Society.

61 Prichard, op. cit. (20), pp. 536-537.

62 H.F. Augstein, James Cowles Prichard's Anthropology: Remaking the Science of Man in Early Nineteenth Century Britain, Amsterdam: Editions Rodopi, 1999, p. 115. 
of peculiarities in children, in consequence of impressions made on the mind of the mother; and, 4thly, The transmission of temporary mental and bodily qualities' ${ }^{63}$ All of these forms of transmission were based on well-established beliefs that could be supported by Combe with evidence from a variety of contemporary sources. It is worth noting that Combe's list does not include the transmission of permanent physical modifications of the body, such as those caused by injury, as he was in agreement with Prichard on the impossibility of this. I will look at each of these modes of transmission in turn, examining the evidence that Combe presents for their reality.

The first type involves the transmission to offspring of temporary states of the body, such as illness or other mental or physical incapacity. Combe first noted that Prichard believed that this was impossible, as only the original attributes of the parents could be transmitted to offspring. However, Combe presented a number of instances of the supposed transmission of temporary states as evidence that Prichard was wrong, including the case of a man who, after suffering from a brain injury, had two children who were both 'idiots'. However, on regaining his faculties after an operation, his subsequent children were normal, as was a child conceived before his accident. The story had been related to Combe by an unnamed medical practitioner from the Isle of Man. Of course, the effect of temporary mental states did not always have to be negative:

even very inferior characters, in whom the moral and intellectual organs are deficient, may be occasionally exposed to external influences which, for the time, may excite those organs to unwonted vivacity; and, according to the rule now explained, a child dating its existence from that period may inherit a brain superior to that of the parent. ${ }^{64}$

Combe also gave an example of the transmission of a temporary physical state, in this case the transmission of udders enlarged by milking in cows, drawn from an article on 'America' in the seventh edition of the Encyclopaedia Britannica (1830-1842).

As for the transmission of acquired habits, Combe gave examples of the behaviour of dogs, sheep and horses to show how patterns of behaviour could be inherited among animals. As is the case throughout Combe's work, his examples are culled from a wide variety of disparate sources taken from his own eclectic reading. The most lengthy example concerns the behaviour of pointer dogs. The information regarding the apparently hereditary hunting behaviour of these dogs was drawn from the Edinburgh Review of August 1825, in a review of a work published anonymously by the poet and translator William Stewart Rose (1775-1843), entitled Thoughts and Recollection by One of the Last Century. Combe does not give any examples of inherited habits among humans, but relies entirely on examples from the animal world.

Turning to Combe's third manner of transmission, that resulting from impressions made on the mind of the mother, it is noteworthy that Combe considered that relatively fleeting impressions or states of mind during pregnancy could have a profound influence on the character of the child. He relied heavily on anecdotal and hearsay evidence as well as published works to support his assertions regarding the transmission of temporary

63 Combe, op. cit. (17), p. 44, original emphasis.

64 Combe, op. cit. (17), p. 47. 
states of the mind and body. He also presented the case of a shoemaker's wife which, he recorded, 'fell under my own observation'. This woman by chance met 'an idiot lad' while she was pregnant. The boy made such 'a strong impression' on the woman that several months later she gave birth to a son 'who is in a state of idiocy' and 'had the slouched and slovenly appearance of the [original] idiot'. ${ }^{65}$ Prichard also had mentioned popular tales of 'mothers longing for various objects, or frightened by unexpected sights during pregnancy, and producing children marked with strawberries, currants, or having visages that resemble pigs' faces'. He considered these to be 'as false as they are improbable', showing himself less prepared to accept somewhat doubtful anecdotal evidence than Combe. ${ }^{66}$ However, even Prichard was prepared to concede 'that at the period when organization commences in the ovum, that is, at, or soon after the time of conception, the structure of the foetus is capable of undergoing modification from impressions on the mind or senses of the parent, does not appear altogether so improbable'. 67

Combe's final manner of transmission was 'the transmission of temporary mental and bodily qualities'. Here Combe relied heavily on the authority of Charles Caldwell (1772-1853), an American physician and phrenologist. Combe quotes from Caldwell's Thoughts on the True Mode of Improving the Condition of Man (1833), a version of which was reprinted in the Phrenological Journal in 1834. Caldwell was also convinced that acquired dispositions could be inherited; for example, he noted that children 'partake of the constitutional qualities of the parents, for the time being. Years and circumstances alter those qualities, and the offspring produced under the influence of them, thus modified, are correspondingly altered'. ${ }^{68}$ For this reason Caldwell was opposed to couples marrying when they were too young, when their constitutions would not yet be mature, or when they were too old, when their constitutions would be enfeebled, lest they give rise to inferior offspring. While Prichard and Caldwell tended to dwell on the inheritance of harmful traits, Combe was equally concerned to show how beneficial characteristics could be inherited.

Although the transmission of acquired characteristics could lead to negative consequences in particular instances, in general Combe was optimistic about its effect on the human species. By exercising the higher faculties of the mind in a manner in harmony with the laws of nature, it was possible for the human race to achieve ever greater perfection in the development of its constitution, just as by allowing the lower, animal faculties free reign and neglecting the natural laws, humanity risked degeneration. But the scales were weighted in favour of development, for the 'Creator has so arranged the external world as to hold forth every possible inducement to man to cultivate his higher powers, nay almost to constrain him to do so'. ${ }^{69}$ In the People's Edition of the Constitution (1835), Combe presented a view of 'the constitution of the world and of

65 Combe, op. cit. (17), p. 45.

66 Prichard, op. cit. (20), p. 555.

67 Prichard, op. cit. (20), p. 555.

68 Charles Caldwell, 'Thoughts on the true mode of improving the condition of man', Phrenological Journal and Miscellany (1832-1836) 8, pp. 605-627, 606.

69 Combe, op. cit. (17), p. 2. 
human nature' in which 'the world, including both the physical and moral departments, contains within itself the elements of improvement, which time will evolve, and bring to maturity; it having been constituted on the principle of a progressive system, like the acorn in reference to the oak'. According to Combe, this view 'affords the richest and most comprehensive field imaginable for tracing the evidence of Divine power, wisdom and goodness in creation'. ${ }^{70}$ The happy outcome of the development and inheritance of the mental faculties was that

there would be improvement in the organic, moral, and intellectual capabilities of the race; for the active moral and intellectual organs in the parents would tend to increase the volume of those in their offspring - so that each generation would start not only with greater stores of acquired knowledge than those which its predecessors possessed, but with higher natural capabilities of turning them to account. ${ }^{71}$

\section{Conclusion}

As Secord has pointed out, Combe 'saw his book as a revolutionary attempt to bring an understanding of human action into the realm of law, and as the founding document in a campaign to create a science that could ensure the future of the human race'. ${ }^{72}$ Combe's view on the perfectibility of humanity through the doctrine of hereditary transmission was part of that vision. Given the spectacular publishing success of the Constitution of Man, Combe's potent blend of hereditarian and progressivist doctrines was to reach a vast audience. We have seen that Combe drew his ideas and evidence on heredity from a range of both contemporary and historical sources. Given their clear relationship with various elements of eighteenth- and early nineteenth-century discourse on heredity and the inheritance of acquired characteristics, there was nothing particularly novel in Combe's ideas on the subject, except perhaps in his linking them with his rather grandiose vision of human progress. His belief that the faculties could be developed during the lifetime of the individual was a natural outcome of his progressivism. Likewise, the inheritance of these acquired characteristics was a necessary prerequisite for the progress made to be passed on to the next generation. It is important to note that Combe stopped at the development of existing organs, and did not envisage that entirely new organs could be gained or existing ones lost through this process. There is no indication that Combe ever imagined that a new species could arise in this manner, or that he ever even considered this possibility. There was therefore a definite limit on how great a change could be accomplished in this way, underlined by Combe's insistence that all living things had received a 'definite constitution' from their creator, which could not be altered.

The belief that new varieties, but not species, could be generated through environmental influences, whether in nature or under domestication, was widely held in the late eighteenth and early nineteenth centuries, and was not generally associated with the

70 Combe, op. cit. (17), p. 4.

71 Combe, op. cit. (17), p. 61.

72 Secord, op. cit. (5), pp. 173-174. 
much more controversial doctrine of the transmutation of species. Combe's belief in the perfectibility of man therefore gives no grounds for linking his theories with contemporary transformism. While not everyone accepted the inheritance of acquired characteristics - Prichard, for example, largely rejected it - the idea had sufficient currency both in the domain of popular anecdote drawn on by Combe and in the expert discourse of medical men such as Hunter and Blumenbach to constitute part of the common-sense understanding of the period. I have argued that Combe's thought developed independently and in all likelihood in ignorance of Lamarckian transformism, although both Lamarck and Combe ultimately drew on hereditarian beliefs which were widespread in the late eighteenth and early nineteenth centuries. Combe's concept of the inheritance of acquired characteristics harks back to the optimistic late Enlightenment belief in the possibility of universal human progress, rather than forward to emerging evolutionary understandings of inheritance. It would be misleading to suggest that the inheritance of acquired characteristics necessarily belonged to a coherent constellation of ideas that included the transmutation of species in this period. This does not, of course, mean that Combe's book and the hereditarian ideas it contained may not ultimately have influenced the popular reception of evolutionary theories later in the century. Combe's promotion of hereditarianism and naturalistic progressivism may well have prepared the ground for the wide acceptance of Robert Chambers's Vestiges of the Natural History of Creation in 1844, and ultimately for Charles Darwin's Origin of Species after 1859. This is perhaps the most important legacy of George Combe's remarkable book. 